\title{
РОЗБУДОВА ТЕОРІЇ ПОЛІТИЧНОЇ ЛІНГВІСТИКИ В УКРАЇНСЬКОМУ НАУКОВОМУ ПРОСТОРІ
}

\section{Тетяна Соловйова}

\author{
Криворізький державний педагогічний університет \\ Kryvyi Rih State Pedagogical University \\ пр. Гагаріна, 54, Кривий Ріг, 50086, Украӥна \\ tetiana_solovei@hotmail.com
}

\begin{abstract}
Соловйова Т. Розбудова теорії політичної лінгвістики в українському науковому просторі

У статті репрезентовано найновіші здобутки в царині української політичної лінгвістики, що сприяли чи сприятимуть розбудові її теоретичних засад; акцентовано увагу на актуальних проблемах українськомовних політико-лінгвістичних розвідок, зокрема на дискусійних моментах у витлумаченні ключових лінгвополітологічних понять; з'ясовано специфіку сучасного політичного дискурсу; окреслено перспективні напрямки наукових лінгвістичних досліджень, зумовлені нинішніми суспільно-політичними реаліями в Україні.
\end{abstract}

Ключові слова: політична лінгвістика, політичний дискурс, мова політики, український політичний дискурс.

Соловьева Т. Развитие теории политической лингвистики в украинском научном пространстве

В статье поднимается вопрос о достижениях в области украинской политической лингвистики, способствующих развитию ее теоретических основ; акцентируется внимание на актуальных проблемах украинскоязычных политико-лингвистических исследований, в частности на дискуссионных моментах в определении ключевых лингвополитологических понятий; рассматривается специфика современного политического дискурса; рассматриваются особенности украинского политического дискурса; определяются перспективные направления научных лингвистических исследований, обусловленные нынешними общественно-политическими реалиями в Украине.

Ключевые слова: политическая лингвистика, политический дискурс, язык политики, украинский политический дискурс. 
Soloviova T. The theoretical studies' development of political linguistics in the Ukrainian science

The article is represented and analyzed the last modern researches in Ukrainian political linguistics; reviewed the actual problem of political Ukrainianspeaking investigations in the political linguistics' area. There are pragmatic, function, typological aspects; semantic paradoxes; idiostyle of politicians; communicative side of the political image etc. Also the author compares different interpretation approaches of the basic concepts of political linguistics: "political discourse", "political language" and noted the necessity for clarification and unification.

It is defined and illustrated such specific features of Ukrainian political discourse such as: variability, transience, dynamism, the appearance of a large number of new concepts, political vectors and a completely different interpretation of the old ones. These ones are related and argued by new sociopolitical phenomena that appeared after the most important and the biggest historical events of Ukraine (The Revolution of Dignity, military aggression of Russia on territory of the East Ukraine and annexation of the Crimea etc.). The author points one side of the problem to determine subject and object in nowadays Ukrainian political discourse: about the place of public organizations in modern Ukrainian politics and place of the most popular bloggers between another sources of political discourse. The prospective directions of scientific linguistic research in Ukrainian politics linguistic are outlined in the purpose study. There are investigation of Ukrainian-speaking political discourse, its' semiotic system, semantic concepts, functional and typology characteristics, suggestive-persuasive possibilities different language units in it etc.

Key words: political discourse, politics linguistic, political language, Ukrainian political discourse.

\section{Постановка проблеми та її зв'язок із важливими} науковими завданнями. Упродовж кількох десятків останніх років “лінгвістичний вимір політичної інформаціï” (Sharova / Шарова 2009 :110) викликає неабияке зацікавлення науковців, що сприяло виокремленню наукової царини, кваліфікованої як політична лінгвістика, або лінгвополітологія. Її появу зазвичай пов'язують чи то 3 другою половиною ХХ ст., чи то 3 початком перебудови, так би мовити, 3 так званою демократизацією суспільства (пор.: “Якщо на Заході проблеми мови і влади, мови й ідеології, мовного маніпулювання, ролі міфів у політичній комунікації і т. ін. перебували у фокусі уваги дослідницького інтересу досить давно - приблизно 3 післявоєнних часів, то в нашій країні (ідеться про Російську Федерацію - Т. С.) лінгвісти активно порушують відповідну проблему переважно 3 початком перебудови..." [Sheihal / Шейгал 2000 : 4]). Відтоді 
3'явилися сотні, а то й тисячі політико-лінгвістичних розвідок, у яких дослідники різних наукових шкіл у той чи в той спосіб порушують питання політичного дискурсу як об'єкта лінгвістичних студій, зокрема питання, пов'язані 3 найрізноманітнішими мовними модифікаціями, зумовленими політичними змінами в певному суспільному просторі; питання теоретичного моделювання політичного дискурсу, виявлення механізмів продукування і функціонування політичних текстів, стратегій і тактик мовленнєвої поведінки тощо. Однак говорити, що на сьогодні політичний дискурс є абсолютно дослідженим, очевидно, було б великим перебільшенням. Адже “боротьба за владу" на сучасному етапі розвитку і науки, і суспільства набуває нових форм, підходів, стратегій, тактик, мотивів і т. ін. А відтак - з'являється і новий лінгвістичний вимір нової (або ж оновленої!) політичної інформації.

Окрім того, можемо констатувати: в українському політичному просторі нині, як ніколи, спостерігається суспільний запит на розуміння, витлумачення й пошук методів ефективного регулювання сфери стосунків в аспекті «соціум влада» задля покращення соціальних умов життя, підняття рівня політичної свідомості, освіченості індивідуумів та ефективності здійснення державного управління. У такому разі актуальність дослідження українськомовного політичного дискурсу крізь призму відповідних аспектів не викликає жодних сумнівів.

Аналіз останніх досліджень та публікацій. Науковці, що по-різному підходять до висвітлення тих чи тих проблем політичного дискурсу, досить часто, демонструючи теоретичні засади дослідження відповідного явища, вдаються до презентації процесу його становлення й розвитку, роблять загалом успішні спроби виокремити в історії вивчення певні періоди, етапи тощо. Маємо змогу спостерігати те, що чимало науковців обирають за так звану точку відліку розглядуваного феномена праці античних філософів Аристотеля та Цицерона [Wilson 2001 : 399-400]. Згідно з позицією Дж. Вілсона, до тих, хто одним із перших акцентував увагу на лінгвістичному аспекті політичного дискурсу, варто зараховувати М. Грейса (ідеться про його працю “The Language of Politics”, що вийшла друком 
у 1987 році). Зародження, становлення i розвиток теорії політичної лінгвістики пов'язують передовсім із іменами науковців далекого й близького зарубіжжя, як-от: Л. Альтюсер, Н. Арутюнова, Р. Барт, М. Бахтін, Б. Бернстайн, Е. Будаєв, Т. Валуєва, Р. Водак, Д. Гакер, Т. ван Дейк, Ж. Деррід, С. Іванова, Д. Камерон, В. Карасик, О. Кубрякова, Ж. Лакан, Т. Литвинова, О. Нахімова, І. Смирнова, Н. Феркло, М. Фуко, Дж. Фьорс, Ю. Хабермас, З. Чанишева, П. Чілтон, А. Чудінов, М. Шапіро, О. Шейгал, Т. Шмельова та ін. [детальніше див.: Budaev, Chudinov / Будаев, Чудінов 2006 : 75-94; Selivanova / Селіванова 2008 : 625-639].

В українськомовному лінгвополітологічному просторі протягом останніх десятиліть спостерігаються суттєві зміни. У науковому обігу з'явилися публікації, у яких порушено низку проблемних (як загальних, так i часткових) питань, що стосуються теорії політичного дискурсу. Мова йде не лише про принагідне висвітлення актуальних моментів феноменального мовного явища (А. Бєлова, І. Бутова, І. Вільчинська, Я. Гнєзділова, О. Косьянова, І. Кусько, Р. Попов, А. Романюк, Л. Ставицька, А. Шарова, І. Шевченко, Н. Шевчук та ін.), а про грунтовні монографічні й дисертаційні праці, виконані як на власне українському, так і на іншомовному матеріалі (М. Бабак, Н. Кондратенко, Л. Нагорна, Н. Петлюченко, В. Петренко, Л. Славова, Л. Стрій, Л. Суховецька, Я. Федорів, О. Фоменко та ін.). У поле зору i молодих, i досвідчених науковців потрапляють питання типології інституційного дискурсу загалом і політичного зокрема, політичний дискурс та мова політики як взаємозалежні категорії, особливості політичного дискурсу (зміст, функції, жанрове втілення), використання комунікативних методів побудови політичного іміджу в засобах масової інформації тощо. У жодному разі не залишається поза їхньою увагою осмислення термінологічного апарату молодої лінгвістичної царини, потрактування ключових понять, аналіз етапів становлення української політичної лінгвістики крізь призму етапів зародження, формування і розвою зарубіжної, окреслення стану і статусу вітчизняної наукової царини і т. ін. [див.: Aleksiievets / Алексієвець; Strii / Стрій 2015 : 20]. 
Метою запропонованої наукової праці $є$ репрезентація найновіших здобутків у царині української політичної лінгвістики, що, своєю чергою, сприяли чи сприятимуть розбудові іï теоретичних засад. Задля досягнення поставленої мети зосередимося на розв'язанні таких основних завдань, якот: 1) виявити актуальні проблеми українськомовних політиколінгвістичних досліджень; 2) з'ясувати специфіку сучасного українського політичного дискурсу; 3) окреслити перспективні напрямки наукових лінгвістичних досліджень, зумовлені нинішніми суспільно-політичними реаліями в Україні.

Виклад основного матеріалу дослідження. Сучасні тенденції глобалізації суспільства сприяють глобалізаційним зрушенням і у сфері політичної лінгвістики. Універсальні підходи до опису й аналізу вербалізованих суспільнополітичних явищ постійно доповнюються, конкретизуються національними, етнокультурними. Звідси, відповідно, i твердження про те, що “політична лінгвістика активніше звертається до принципово нових проблем сучасного багатополярного світу. Сфера наукових інтересів нової науки розширюється внаслідок залучення до аналізу актуальних аспектів взаємодії мови, влади і суспільства (дискурс тероризму, дискурс “нового світового порядку”, політкоректність, соціальна толерантність, соціальна комунікація в традиційному суспільстві, фундаменталістський дискурс та ін.)" [Aleksiievets / Алексієвець]. Науковець беззастережно зауважує: здобутки українських дослідників великою мірою грунтуються на досягненнях зарубіжних колег. Акцентується насамперед на тому, “що українські лінгвісти прагнуть осмислити загальні категорії політичної лінгвістики, сформулювати теоретичні основи науки, охарактеризувати поняттєвий апарат i термінологію; продовжують досліджувати зміни в політичній лексиці, фразеології, стилістиці; намагаються розглянути специфіку окремих жанрів політичної мови, закономірності організації політичного тексту, проблеми мовної рефлексії й суб' єктивної модальності, оцінки, точки зору, впевненості; здійснюють дослідження ідіолектів найвідоміших зарубіжних й українських політичних лідерів, а також загальних 
закономірностей комунікативних стратегій i тактик у політичному дискурсі” [Aleksiievets / Алексієвець]. Цей далеко не повний перелік досліджуваних питань увиразнюється іменами, 3 якими пов'язують розбудову теоретичних i концептуальних засад політичної лінгвістики. Українські науковці постійно наголошують на необхідності провадження досліджень у сфері вітчизняної політичної лінгвістики. Так, відповідно до позиції Л. Нагорної лінгвополітологія зможе зайняти чільне місце в українській науці, якщо “рівною мірою досліджуватиметься і вплив мови на політику, і вплив політики на мову та етнічну сферу" [Nahorna / Нагорна 2006 : 166].

Аналіз українськомовних студій, присвячених дослідженню лінгвістичного виміру політичної інформації, дає підстави стверджувати, що українська політична лінгвістика донині не має у своєму розпорядженні чітких і загальних витлумачень ключових понять. Наприклад: термінологічне словосполучення політичний дискурс отримує такі потрактування: 1) “конкретний вияв політичної комунікації, що передбачає актуалізацію політичного тексту в комунікативному акті взаємодії політичного суб'єкта (політика, політичної сили, влади) та політичного об'єкта (аудиторії, електорату, виборця)" [Kondratenko / Кондратенко 2007 : 12]; 2) “складна ідеологічно сконструйована засобами 3МI та іншими комунікативними джерелами єдність комунікативної поведінки і прагматичних, політичних, соціокультурних i психологічних чинників, що являють собою системно-символічний порядок, у межах якої реалізується процес боротьби за владу" [Shevchuk / Шевчук 2013 : 267]; 3) “сукупність політичних текстів, що циркулюють у соціумі, продукуючи та закріплюючи значення за політично значущими символами й концептами, які стають критеріями правильності чи неправильності дій у межах певного соціуму” [Kryvenko / Кривенко 2016: 36], тобто політичний дискурс “є тематичною мережею політичних текстів, об'єднаних однією темою, яка детермінує взаємозв’ язок дискурсу з прагматичними, соціологічними, психологічними, культурними, лінгвістичними та іншими площинами" [Kryvenko / Кривенко 2016: 36]. Політичний дискурс зазвичай витлумачують (чи то пов'язують)

(C) Т. Соловйова, 2018. 
i3 політичною комунікацією, із суб'єктами політичної діяльності, боротьбою за політичну владу, модифікацією політичної картини світу тощо.

Важливим здобутком вітчизняної лінгвополітології вважаємо працю О. Селіванової “Сучасна лінгвістика: напрямки та проблеми” (2008р.), де на тлі основних напрямків сучасного світового мовознавства вирізняються дискурсологія та політична лінгвістика, невід'ємними аспектами вивчення яких $€$ політичний дискурс та мова політики [Selivanova / Селіванова 2008]. Дослідниця окреслює десять завдань політичної лінгвістики, що стосуються або політичного дискурсу загалом (як-от: “характеристика особливостей політичного дискурсу” чи "моделювання його базових концептів 3 описанням мовних засобів їхньої репрезентації”), або його часткових аспектів (“дослідження маніпулятивних стратегій”, “установлення функцій мови в політичній комунікації, “опис мови політиків” тощо) [Selivanova / Селіванова 2008 : 353].

В українському науковому просторі спостерігаються суперечності й у витлумаченні понять “мова політики" / “політична мова". Так, скажімо, Н. Кондратенко висловлює думку про недоцільність використання відповідної термінології, аргументуючи це тим, що політики (політика) послуговуються системою одиниць конкретної загальнонаціональної мови, надають перевагу певним лексичним одиницям або синтаксичним конструкціям. Політика не має окремої власної семіотичної системи впорядкованих вербальних одиниць, організованих певним чином, яку номінують мовою. Лінгвіст вважає, що закономірно в такому разі використовувати термінологічні словосполучення “політичне мовлення" чи “мовлення політики", які вказують на “спосіб реалізації національної мови”, а не на функціонування окремої вербальної системи знаків [Kondratenko / Кондратенко 2007 : 23-24].

Поліваріантність спостерігаємо й у потрактуванні співвідношення термінів "мова політики" та "політичний дискурс". Приміром, Л. Нагорна ототожнює ці поняття, розглядає їх як аналогічні концепти [Nahorna / Нагорна 2005 : 162], О. Косьянова вважає, що ці категорії є взаємозалежними: 
політична мова $є$ сукупністю та взаємодією “різнорідних документів, політичних структур i політичних організацій, виступів i висловлень політичних діячів, публікації фактографічного й аналітичного характеру у пресі про певні політичні події, інформацію на телебаченні й радіо про політичні події”; політичний дискурс - “уживання мови в соціально-політичній сфері спілкування i, ширше, у публічній сфері спілкування" [Kosianova / Косьянова 2013].

Гадаємо, на сучасному етапі розвитку політичної лінгвістики уточнень потребують найуживаніші категорійні поняття: і політичний дискурс, і політична комунікація, і навіть політична лінгвістика. Адже сучасні українські реалії ставлять перед науковцями ряд проблемних питань. Наприклад: Кого слід вважати політичним діячем? Чи можна зараховувати до цієї категорії дослідників політичного дискурсу, політики як такої (політологів, соціолінгвістів, аналітиків та ін.)? Чи варто уналежнювати їхні висловлення, наукові тексти до тих чи тих жанрів політичного дискурсу? тощо.

Відкритим питанням залишається і сфера політичних масмедіа, особливо за умови аналізу вітчизняного політичного дискурсу 3 урахуванням усіх суттєвих соціально-політичних реалій нашої країни. Наприклад, в Україні немає суто політично спеціалізованих засобів масової інформації (активних, регулярних, всеукраїнського масштабу). У такому разі, можливо, логічно було б долучити до політичного дискурсу всі тексти ЗМІ політичного змісту. Поза увагою залишається питання й стосовно належності / неналежності до політичного дискурсу текстів блогерів політичної тематики, передусім тих, які $є$ найбільш відомими у країні. У сучасній політичній сфері засвідчено чимало фактів, коли відповідні комунікативні посили мали безпосередній вплив на дії політиків, зміну політвекторів, ініціативи створення певних законів (блоги найвідоміших волонтерів РУВ (АТО), громадських активістів та ін.).

Вочевидь, варто згадати і про громадські організації й інші громадські формування, які навіть в офіційних статутах не передбачають провадження політичної діяльності. Утім, у сучасній українській політичній практиці набуло поширення 
явище використання певних суспільних формацій задля реалізації політичної мети: від публічного оприлюднення членами тієї чи тієї організації політичної риторики до остаточного переходу їхніх керівників у сферу політичної діяльності (Дмитро Булатов - народний депутат VIII скликання, колишній співораганізатор громадського руху “Автомайдан”; Ігор Луценко - народний депутат VIII скликання, засновник громадського руху “Збережи старий Київ”), а то й до повного переформатування громадських організацій у політичні проекти (“Правий Сектор”, “Демальянс" та ін.).

Виникає логічне питання: чи доцільно оминати політичну або навіть, на перший погляд, неполітичну риторику таких громадських формувань, якщо вона чи то активно використовується політиками, чи то, можливо, штучно створена під певну політичну силу?

На нашу думку, у широкому витлумаченні політичного дискурсу в контексті його потрактування як різновиду інституційного, зазначені аспекти варто розуміти як неподільні, оскільки вони $є$ не лише частиною сучасної політичної картини України, але й активно впливають на ії подальші зміни й розвиток.

Упадає в око те, що деякі науковці пов'язують проблему дослідження українського політичного дискурсу 3 несформованістю українського політичного простору: від моменту проголошення незалежності України до сьогодення не відбувся процес концептуалізації політичної реальності нашої держави: “триває процес становлення політичного простору, уякому колишня система політичних інститутів i зв'язків зруйнована, а нова ще не склалася" [Popov / Попов]. Цей процес ускладнюється ще й тим, що попередня (радянська) політична система пронизувала абсолютно всі сфери суспільного життя, сьогодні ж простежується тенденція до відокремлення політичної сфери від інших суспільних інститутів. Р. Попов визначає два шляхи розвитку політичного дискурсу для України: орієнтований на минуле комуністичний дискурс та орієнтований на майбутнє ліберальний дискурс [Popov / Попов]. 
Запропоноване формулювання моделей розвитку українського політичного дискурсу викликає ряд питань 3 огляду на сучасні суспільно-політичні явища, соціальні перетворення й перевороти, які переживає українське суспільство. Події 2013-2014 pp. (Революція Гідності) чітко визначили можливі політичні вектори на майбутнє, серед яких важко віднайти такий, який можна було б потрактувати як лише ліберальний. Натомість ці події повністю відторгли орієнтир на комуністичний політичний дискурс в Україні, що підтверджується поширенням і розвитком такого суспільнополітичного явища, як декомунізація. Воно виникло українському політичному просторі значно раніше (як програмова засада українських політичних партій, які сповідують ідеологію українського націоналізму), однак широкої популярності набуло під час революційних подій. Реалізація ж заходів декомунізації почалася стихійно, з прямої ініціативи суспільства, часто дещо радикальними методами (так звана “народна декомунізація"), згодом іiі засади були закріплені законодавством України. Причини відповідних суспільних модифікацій навряд чи можна вважати ліберальними, швидше націоналістичними, радикальними. Події тих років не лише змінили змістовну наповнюваність певних концептів політичного українського дискурсу, але й сприяли виникненню нових, i відповідно, сприяли появі нового вербального наповнення.

Подібні тенденції швидких змін, розвитку, виникнення нових явищ у політичному дискурсі України спостерігаємо і в результаті анексії Криму та початку військових дій на території східних областей нашої держави. Зокрема посилюються ідеї національної самоідентифікації членів українського суспільства, проблема двомовності на теренах України набуває суттєво інших відтінків: так, питання обстоювання ідей двомовності на державному рівні (функціонування на рівних правах як державних мов української та російської) на сьогодні перейшло із площини політичних позицій до площини політичної безпеки i може бути потрактоване як зрада державних інтересів i підтримка 
сепаратистських угруповань. Така конотація подібної політичної позиції спричинена передовсім військовою агресією Російської Федерації проти України, що ії офіційно пояснюють як “захист російськомовного населення в Україні”.

3 огляду на сказане вище, можна виокремити ще один можливий орієнтир українськомовного політичного дискурсу “проросійський”, або “федеративний”, явною відправною точкою якого можна вважати початок президентства В. Януковича. Загостренням суперечностей між цим орієнтиром та дещо протилежним (назвемо його “демократичним”, або “україноцентристським”) стало так зване АТО, а по суті, російсько-українська війна на території Східної України.

Такі глобальні події в історії українського соціуму не лише активно впливають, а фактично визначають напрямки розвитку українського політичного дискурсу, його особливості, характеристики, тенденції, принципи конструювання подальших його моделей. Беручи до уваги провідну роль мовного питання у процесі важливих суспільно-політичних змін, на новий щабель піднімається проблема українського політичного дискурсу загалом і його українськомовної частини зокрема. Ця частина, якщо порівнювати 3 мовно-національною структурою політичного дискурсу 90-их рр. попереднього століття, збільшилася в рази, що, своєю чергою, має сприяти якіснішому iï наповненню. Подальша розбудова теорії української політичної лінгвістики й українськомовного політичного дискурсу потребує глибокого й усебічного наукового дослідження, опису, аналізу, систематизації його явищ, принципів, особливостей, елементів.

\section{Висновки та перспективи подальших наукових} розвідок. Здійснивши побіжний огляд сучасних наукових досліджень у царині української політичної лінгвістики, можемо констатувати: інтерес науковців до феномена політичного дискурсу активно зростає, про що свідчить і кількісне збільшення праць українських мовознавців, i розширення спектру досліджуваних проблем та аспектів політичної лінгвістики. Сучасні вітчизняні лінгвополітологічні праці скеровують вектори свої досліджень на розв'язання таких 
проблем, як-от: окреслення нових підходів до потрактування політичної лінгвістики загалом і політичного дискурсу зокрема; виявлення диференційних ознак політичного дискурсу; репрезентація його жанрової класифікації; з'ясування лінгвістичних особливостей кожного 3 жанрів; репрезентація прагматичного аспекту політичної комунікації та комунікативного аспекту побудови політичного іміджу; демонстрація семантичної парадоксальності в політичному лінгвопросторі; характеристика ідіостилів відомих політиків.

3 огляду на мінливість, швидкоплинність, динамічність, виникнення великої кількості нових концептів, політичних векторів і кардинально інше потрактування раніше усталених понять постає питання про розбудову теоретичних засад політичної лінгвістики в українському науковому просторі. Бурхливе сьогодення, боротьба за владу в різних ешелонах i т. ін., 3 одного боку, змістовно наповнюють український політичний дискурс, надають йому специфічно національних рис, $з$ іншого, - ускладнюють витлумачення його поняттєвого апарату. Тому перспективними напрямками наукових лінгвістичних розвідок у царині політичної лінгвістики, на нашу думку, $є$ різнобічне дослідження українськомовного політичного дискурсу: його мовно-семіотичної системи, смислових концептів, функційно-типологійних характеристик, сугестивно-персуазивних можливостей різнорівневих мовних одиниць і т. ін.

\section{Література}

1. Алексієвець О. Історія та сучасність політичної лінгвістики. URL : http://shron1.chtyvo.org.ua/Aleksiievets_Oksana/Istoriia_ta_suchasnist_politychnoi linhvistyky.pdf.

2. Будаев А. В., Чудинов А. П. Зарубежная политическая лингвистика : учебн. пособ., 2006. 252 c. URL : https://www.twirpx.com/ file/213406/.

3. Кондратенко Н. В. Український політичний дискурс: текстуалізація реальності : монографія. Одеса, 2007. $156 \mathrm{c.}$

4. Косьянова О. Г. Мова політики та політичний дискурс як взаємозалежні категорії. Англістика та американістика. 2013. Вип. 10. С. 20-23. URL : http://nbuv.gov.ua/UJRN/antame_2013_10_8.

5. Кривенко С. О. Семантична парадоксальність політичного дискурсу (теоретико-методологічний аналіз) : дис. ... канд. політ. наук : 23.00.01. Львів, 2016. $216 \mathrm{c}$.

(с) Т. Соловйова, 2018. 
6. Нагорна Л. Політична лінгвістика : стан і статус. Наукові записки Інституту політичних $і$ етнонаціональних досліджень ім. І. Ф. Кураса НАН України. 2006. Вип. 30 (2). С. 160-168. URL : http://nbuv.gov.ua/ UJRN/ Nzipiend_2006_30\%282\%29_18.

7. Попов Р. А. Політичний дискурс: проблема теоретичної ідентифікації. URL : http://academy.gov.ua/ej/ej2/txts/pol-prav/05 prapti.pdf.

8. Селіванова О. О. Сучасна лінгвістика : напрями та проблеми : підручник. Полтава : Довкілля-Київ, 2008. 712 с.

9. Стрій Л. І. Ритуальні жанри українського політичного дискурсу : структурно-семантичний і лінгвопрагматичний аспекти : дис. ... канд. філол. наук : 10.02.01. Одеса, 2015. 190 c. URL : http://onu.edu.ua/pub/ bank/userfiles/ files/science/rada\%20philology/Дисертація\%20_Стрій.pdf.

10. Шарова А. М. Лінгвістичний вимір політичної інформації : становлення політичної лінгвістики. Політологія. Наукові праці. 2009. Т. 110. Вип. 97. C. 110-117. URL : http://nbuv.gov.ua/UJRN/ Npchdupol_2009_110_97_23.

11. Шевчук Н. В. Особливості політичного дискурсу: зміст, функції, жанрове втілення. Вісник ДАКККіМ. Політологія. Вип. 1. 2013. С. 263-269. URL: http://journals.uran.ua/visnyknakkkim/article/download/137414/ 134317.

12. Шейгал Е. И. Семиотика политического дискурса : дис. ...д-ра филол. наук : 10.02.19. Волгоград, 2000. 440 с.

13. Wilson J. Political Discourse. Handbook of discourse analysis / edited by D. Schiffrin, D. Tannen, H. Hamilton. Blackwell Publishers Ltd, 2001. P. 398-415. URL : https://g411.files.wordpress.com/2013/08/ discourse-analysis-full.pdf.

\section{References}

1. Aleksiievets O. Istoriia ta suchasnist politychnoi linhvistyky. URL : http://shronl. chtyvo.org.ua/Aleksiievets_Oksana/Istoriia_ta_suchasnist_politychnoi_linhvistyky.pdf.

2. Budaev A. V., Chüdynov A. P. Zarubezhnaia polytycheskaia lynhvystyka : uchebn. posob., 2006. 252 s. URL : https://www.twirpx.com/ file/213406/.

3. Kondratenko N. V. Ukrainskyi politychnyi dyskurs: tekstualizatsiia realnosti : monohrafiia. Odesa, 2007. $156 \mathrm{~s}$.

4. Kosianova O. H. Mova polityky ta politychnyi dyskurs yak vzaiemozalezhni katehorii. Anhlistyka ta amerykanistyka. 2013. Vyp. 10. S. 20-23. URL : http://nbuv. gov.ua/UJRN/antame_2013_10_8.

5. Kryvenko S. O. Semantychna paradoksalnist politychnoho dyskursu (teoretyko-metodolohichnyi analiz) : dys. ... kand. polit. nauk : 23.00.01. Lviv, 2016. $216 \mathrm{~s}$.

6. Nahorna L. Politychna linhvistyka : stan i status. Naukovi zapysky Instytutu politychnykh $i$ etnonatsionalnykh doslidzhen im. I. F. Kurasa NAN Ukrainy. 2006. Vyp. 30 (2). S. 160-168. URL : http://nbuv.gov.ua/ UJRN/Nzipiend_2006_30\% $282 \% 29$

7. Popov R. A. Politychnyi dyskurs: problema teoretychnoi identyfikatsii. URL : http://academy.gov.ua/ej/ej2/txts/pol-prav/05 prapti.pdf.

8. Selivanova O. O. Suchasna linhvistyka: napriamy ta problemy: pidruchnyk. Poltava : Dovkillia-Kyiv, 2008. 712 s. 
9. Strii L. I. Rytualni zhanry ukrainskoho politychnoho dyskursu: strukturnosemantychnyi i linhvoprahmatychnyi aspekty : dys. ... kand. filol. nauk : 10.02.01. Odesa, 2015. 190 s. URL : http://onu.edu.ua/pub/ bank/userfiles/files/science/rada\% 20philology/Dysertatsiia\%20_Strii.pdf.

10. Sharova A. M. Linhvistychnyi vymir politychnoi informatsii: stanovlennia politychnoi linhvistyky. Politolohiia. Naukovi pratsi. 2009. T. 110. Vyp. 97. S. 110117. URL : http://nbuv.gov.ua/UJRN/ Npchdupol_2009_110_97_23.

11. Shevchuk N. V. Osoblyvosti politychnoho dyskursu : zmist, funktsii, zhanrove vtilennia. Visnyk DAKKKiM. Politolohiia. Vyp. 1. 2013. S. 263-269. URL: http://journals.uran.ua/visnyknakkkim/article/download/137414/ 134317.

12. Sheihal E. Y. Semyotyka polytycheskoho dyskursa: dys. ...dokt. fylol. nauk : 10.02.19. Volhohrad, 2000. $440 \mathrm{~s}$.

13. Wilson J. Political Discourse. Handbook of discourse analysis / edited by D. Schiffrin, D. Tannen, H. Hamilton. Blackwell Publishers Ltd, 2001. P. 398-415 URL : https://g411.files.wordpress.com/2013/08/ discourse-analysis-full.pdf.

Стаття надійшла до редакиії 30.09.2018 p. Прийнята до друку 15.11. 2018 р. 